\title{
Intelligent Street Lighting in a Smart City Concepts-A Direction to Energy Saving in Cities: An Overview and Case Study
}

\author{
Konrad Henryk Bachanek ${ }^{1} \mathbb{D}^{\mathbb{D}}$, Blanka Tundys $^{1} \mathbb{D}$, Tomasz Wiśniewski ${ }^{1} \mathbb{D}$, Ewa Puzio $^{1}$ and $^{-}$ \\ Anna Maroušková 2,3,*iD \\ 1 Faculty of Economics, Finance and Management, Institute of Management, University of Szczecin, \\ Cukrowa 8, 71-004 Szczecin, Poland; konrad.bachanek@usz.edu.pl (K.H.B.); blanka.tundys@usz.edu.pl (B.T.); \\ tomasz.wisniewski1@usz.edu.pl (T.W.); ewa.puzio@usz.edu.pl (E.P.) \\ 2 Faculty of Technology, Institute of Technology and Business in České Budějovice, Okružní 517/10, \\ 370-01 České Budějovice, Czech Republic \\ 3 Faculty of Economics, University of South Bohemia in České Budějovice, Studentská 13, \\ 370-05 České Budějovice, Czech Republic \\ * Correspondence: anna.marouskova@gmail.com
}

Citation: Bachanek, K.H.; Tundys, B. Wiśniewski, T.; Puzio, E.;

Maroušková, A. Intelligent Street

Lighting in a Smart City Concepts-A Direction to Energy Saving in Cities: An Overview and Case Study. Energies 2021, 14, 3018. https://doi. org/10.3390/en14113018

Academic Editor: Umberto Berardi

Received: 14 March 2021

Accepted: 20 May 2021

Published: 23 May 2021

Publisher's Note: MDPI stays neutral with regard to jurisdictional claims in published maps and institutional affiliations.

Copyright: (c) 2021 by the authors. Licensee MDPI, Basel, Switzerland. This article is an open access article distributed under the terms and conditions of the Creative Commons Attribution (CC BY) license (https:/ / creativecommons.org/licenses/by/ $4.0 /)$.

\begin{abstract}
The aim of the article is to present and analyze the implementation of intelligent lighting within the concept of smart energies and smart cities. Motivation and research hypothesis: Electricity consumption in the world is based largely on non-renewable energy. Until these full changes, it is necessary to look for opportunities to save and use it efficiently. Today's cities are increasingly implementing the smart concept, of which smart energy is one area. One of the smart city elements implemented by cities is smart energy. Within this framework, a supported concept is the replacement of traditional lighting with LEDs (Light-Emitting Diodes), which contributes to energy and cost savings and reduces the pollution of the sky with artificial light, while increasing the efficiency of urban lighting. Positive effects of modern solutions include reduced lighting expenses and increased safety of residents. Methods and results of the research: The authors chose the case study method for their research. The authors present forecasts for the development, not only from the point of view of the number of lamps but also the cost efficiency pointing out the importance of this element in the context of building smart cities. These are specific benchmarks for cities that have not yet implemented this concept. Conclusions and interdisciplinary implications: solutions are desirable directions for the development of the smart city concept, bringing benefits and reducing external costs. Considerations show a quantitative development forecast and an indication of the possibility of achieving trade-offs and cost reductions. It translates into meeting the requirements of sustainable development providing tangible benefits. The analysis of the case studies is intended to show the effects that can be achieved and the wide range of applications (indicating that modern lamps are not just lighting, but a platform for urban services). The analyses presented are intended to serve as benchmarks showing the possibilities of reducing costs and increasing the quality of life of residents in modern cities. The indicated examples and analyses are of economic importance, they show managers, but also inhabitants, in which direction they should lead the smart city concept, which will allow saving costs, but also to increase the quality of life of inhabitants.
\end{abstract}

Keywords: smart city; energy; street lighting; LED lighting

\section{Introduction}

Global electricity consumption is reaching considerable figures and increasing by around 3\% each year. Outdoor lighting is responsible for $15-19 \%$ of global electricity consumption, lighting represents something like $2.4 \%$ of the annual energetic resources of humanity, accounting for $5-6 \%$ of the total greenhouse gas emissions to the atmosphere $[1,2]$. 
Atmospheric concentrations of carbon dioxide $\left(\mathrm{CO}_{2}\right)$, methane, and nitrous oxide have increased by $40 \%$ compared to the pre-industrial era, mainly due to the burning of fossil fuels [3]. According to estimates, cities consume almost $75 \%$ of global energy, and outdoor urban lighting alone can account for as much as $20-40 \%$ of budget expenditure related to power [4]. LED (Light-Emitting Diodes) lighting achieves energy savings of 50-70\% compared to the old technologies. Switching to LED lighting can bring considerable benefits to tight city budgets. It estimates that a global transition to energy-efficient LED technology would save more than 1400 million tonnes of $\mathrm{CO}_{2}$ and avoid the construction of 1250 power plants [5]. In this context, it is essential to implement solutions that allow for the proper management of the natural environment and human-made artificial environment [6]. The answer to these challenges may be intelligent lighting, which is part of the smart city concept. It is essential to fulfill world agreement that has established the reduction of greenhouse gas emissions by $80-90 \%$ by 2050 [7]. The main reason for the increase in anthropogenic emissions is the dramatic increase in consumption of fossil fuels, i.e., coal, oil, and gas. The world's population is also increasing, as is consumption per capita. It is believed that in the development of technologies limiting the amount of $\mathrm{CO}_{2}$ emitted, a large role is played technology related to its capture and storage will play, respectively selected geological formations (CCS- $\mathrm{CO}_{2}$ Capture and Storage). This is where CCS technology contributes perhaps up to a $20 \%$ reduction in $\mathrm{CO}_{2}$ emissions expected by 2050 [8]. There are three methods of carbon capture: pre-combustion, post-combustion, and oxy-combustion [9]. Many developed countries have already started the process of ending/banning the use of fossil fuels_at the beginning of 2021, a joint communiqué of the ministers of the European Union countries was announced, calling for the global abandonment of coal in the energy sector and the cessation of subsidizing fossil resources. Natural gas can be replaced with biogas [10], carbon is being replaced by carbonized bio-waste [11], and instead of diesel, biodiesel or vegetable oil can be used [12]. Increasing the share of renewable and innovative energy leads to a reduction of $\mathrm{CO}_{2}$ emissions [13].

Innovation and high-tech solutions lead to savings of $40 \%$ in this area. This would be equivalent to a 50\% reduction in emissions from electricity and heat [1]. It gives about EUR 2 billion in funding at the EU level as a whole and 50\% of the cost of maintaining energy infrastructure while improving the efficiency of energy systems by $1.5 \%$. The implementation of modern energy-using products in cities requires the improvement of their efficiency, e.g., longer working hours with a simultaneous increase in environmental efficiency [14]. Investments in urban infrastructure are key to the development of smart cities [15]. Smart lighting is one such investment. By changing from outdoor lighting to modern LEDs from a global perspective, street lighting alone indicates energy cost savings of about EUR 18.8 billion, prevent 221 power plants from being built, and avoid 245 million tons of $\mathrm{CO}_{2}$ emissions. If this translates into all sectors of the economy, switching to lighting could lead to energy cost savings of EUR 187.1 billion, prevent 1250 power plants from being built, and avoid 1400 million tons of $\mathrm{CO}_{2}$ emissions [16,17]. The global problem is the increasing carbon footprint. Since the 1960s, the carbon footprint has increased more than 11 times [18]. Energy production generates the second-largest share of greenhouse gas emissions. In the US, it accounted for $26.9 \%$ of GHG emissions, and about $63 \%$ of electricity comes from burning fossil fuels, mostly coal and natural gas [19]. $\mathrm{CO}_{2}$ emissions have increased by about $90 \%$ since 1970; emissions from nonrenewable energy sources and industrial processes account for about $78 \%$ of the total increase in greenhouse gas emissions [20]. It is often identified as a result of logistical processes, including transport, production, and storage. However, energy consumption also accounts for a large part of this. The rapid growth of the urban population and the increase in energy needs in cities forces a change in thinking and the search for innovative ideas and solutions that will mitigate the adverse effects of increasing energy consumption. Traditional power sources are ineffective. Street lighting is one of the essential elements of critical urban infrastructure. A modern, extensive, safe, and economically efficient street lighting network and accompanying services within the smart city system can be a solution to some of the economic, social, 
and environmental problems in cities. The use of LED lamps is becoming more and more common, especially due to the possibility of cost savings, the natural environment [21-23], but also the multifunctionality offered by installing intelligent streetlamps. The use of modern, intelligent lighting in cities contributes to reducing expenditure on lighting, increasing the safety of citizens, and reducing sky pollution (through the use of appropriate intensity and color of lights), for example, the paper by J. Kowalska [24]. Modern street luminaires of LED lamps can be connected to an advanced remote management system that allows the programming of luminaire operation scenarios. The light intensity can be adjusted to the weather conditions on a given day (sudden deterioration of conditions, faster darkening due to, e.g., an approaching storm, fog, heavy rainfall), depending on the season, or reduce at the least frequented sections. The implemented investments, although costly and time-consuming, bring positive effects for all stakeholders and should be a good example for all cities. The replacement of traditional street lighting with cost-effective LEDs not only contributes to cost savings for cities in urban lighting but is also part of the modern concept of city development-smart cities. Modern lamps can be used, not only in a traditional way but with the entire infrastructure (pole, bulb) they can serve as an element of a virtual smart city platform. In addition, modern street lighting solutions contribute to a reduction in electricity consumption, thereby reducing air pollution, and modern spotlighting does not pollute the night sky [25]. The problem of electricity use in cities is one of the elements and research areas of a smart city. Therefore, the researcher's problems in this area related to the use of intelligent street lighting is a scientifically and practically important area that should be reflected in scientific works. Indication of case studies can become not only an inspiration for different types of territorial units and cities but also be a basis for developing the contribution of such solutions to scientific research related to the possibilities of energy savings in cities. The problems addressed are not limited to regions, the case studies can serve as examples and benchmarks for any city in the world. Dedicated as well as universal solutions should be tailored locally, but the urgency of the solutions is related to the need to reduce energy expenses in cities and to protect the environment by using more efficient and optimal energy sources (e.g., for urban street lighting). The urgency of change is linked to the need to respect the principles of sustainable development, which applies globally.

The remainder of this paper is organized as follows. Section 2 presents a literature review on the presented topic. In Section 3, a synthesis of the main materials and methods is presented. Section 4 presents results of the empirical research in the area of energy demand, smart lighting, and smart energy as a part of smart city concepts and the most important presentation of the case studies. In Section 5 it was included discussion, Section 6 presented conclusions.

\section{Literature Review}

The development of smart cities poses many challenges for the authorities, not only related to them adapting technology to the needs and expectations but also with care for the environment.

The term smart city has many definitions, but on the basis of a detailed review of the literature on the subject, the authors assume for the purposes of further considerations that smart cities are cities with a development strategy focusing on creativity, openness to innovation, and flexibility, understood as the ability to quickly adapt to external and internal conditions. These are cities that use modern technologies to improve the quality of life of their inhabitants while fighting the negative effects of ecosystem degradation.

High-quality LED lighting improves the quality of life in the city by providing the right light that makes the streets brighter and safer [26]. Providing solutions that will be modern, efficient, and energy-saving at the same time and human-friendly. This is the goal that lighting designers and manufacturers are trying to achieve. The conducted research proves that thanks to the implementation of innovative technology life, it will become more 
convenient in the city, and the costs related to energy use and infrastructure maintenance will be lower $[2,3,7,13,27,28]$.

Scientists also prove that street lighting can significantly reduce energy demand and reduce $\mathrm{CO}_{2}$ [29]. Out of concern for the natural environment, producers of advanced technologies are trying to improve lighting so that it is as energy-efficient and ecological as possible. The sensors will allow you to adjust the light intensity to the conditions, the spotlighting of individual light sources, responding to the appearance of pedestrians or cyclists, will also help minimize power consumption. Streetlamps may also have additional functions-such as electric bike charging stations, which will reduce the emission of carbon dioxide into the atmosphere.

In recent years, scientists from around the world have put a lot of effort into identifying the most important factors influencing energy saving, which results in an improvement of the environment in which inhabitants of smart cities live. Most scientists emphasize that the most important factors are energy planning and innovative urban solutions that help reduce energy losses [27-30].

Cities are currently the largest energy-consuming center; therefore a big challenge is to plan long-term activities while ensuring maximum efficiency of the city's energy system. Interestingly, Klaassen et al. [28] showed in their article that any manifestation of pro-ecological solutions in the city results in a significant reduction of the carbon footprint and ecological costs and shows long-term benefits for residents. It is observed that the use of the street lighting control and monitoring system and other smart city elements generates measurable savings.

This aspect is the perfect business case for smart city authorities to invest in modern technologies such as smart street lighting.

\section{Materials and Methods}

The case study methodology is used for qualitative research [31]. Such an approach aims to describe and explain the phenomenon indicating in such a way as to achieve an appropriate level of complexity [32]. This type of research can take a holistic approach and explore social processes that are complex [33]. The case study should correspond to the theoretical assumptions, being an extension of them, identifying new categories in theory, or showing positive or negative cases corresponding to a given scope of the described approach. Based on considerations and case study design [33], it can indicate that the authors have chosen the method: external validity, in which to demonstrate that the domain to which a case study's findings belong can be generalized. For quantitative analysis were used materials and reports from available public databases, statistical offices, and official websites of cities and companies producing and supplying energy and lighting infrastructure.

The research process was conducted in two steps. In the first step, an analysis was carried out of statistical data related to electricity consumption in each country over the last 30 years. This analysis allows conclusions to be drawn in relation to changes in electricity consumption and an indication of levels of energy consumption and expenditure on urban lighting. The focus was then on identifying technologies and assumptions related to street lighting, with a particular focus on LED. The next step of the research analysis was to identify the essence of smart energy in the smart city concept. The second track of research is concluded with the presentation of case studies. Their choice is not accidental, focusing on modern solutions that are either part of a larger concept, are innovative, and can serve as benchmarks for other cities in the world. The indicated methodology aims to indicate the practical possibilities and positive effects to be achieved by popularizing LED lighting in cities. 


\section{Results}

\subsection{Energy Demand}

The increasing population of the Earth, as well as the general trend to get richer and raise the standard of living, affect the growing demand for raw materials and energy. Data from United Nations (UN 2019) show that 2030 will increase by a billion, from 2000 to 7.8 billion to 8.6 billion in 2030. In 2050, the world will already have 9.8 billion people, and in 2100 as much as 11.2 billion [34]. Such population growth will result in an ever-increasing demand for fuel and energy.

The rapid development of renewable energy sources is not keeping pace with the increasing electricity demand. Total energy demand worldwide has increased in 2018 by $2.3 \%$, and for electricity almost twice as much-by $4 \%$ (about $900 \mathrm{TWh}$ ) [35]. This is the fastest pace since 2010. By 2050, the Energy Information Administration (EIA) report shows data showing an almost 50\% increase in energy consumption (compared to 2018) [4]. This is due to the next edition of the International Energy Outlook 2020 report, published on 24 September, containing forecasts of changes in energy production and consumption in the world [4]. Electricity consumption can be related to micro- and macroeconomic levels. The analysis of energy efficiency considered at the micro-level concerns the technological possibilities of energy management. Analyzed at the macroeconomic level, energy efficiency is assessed by energy consumption, it shows how much is used for one euro or another currency [19]. Energy plays a central role in national economic development. It may also have a leverage effect on economic growth [36].

The increase in energy consumption in the industry (by EIA also means agriculture and construction, among others) forecasts at 30\% (all percentages are given here relate to the period between 2018 and 2050) [37]. Energy consumption in transport may increase by $40 \%$, of which in non-OECD countries by almost $80 \%$ [38]. The transportation of passengers and goods is developing in these countries much faster than, for example, in the USA or European Union countries. The building sector expects to increase energy consumption by $65 \%$ [39]. This is to be related mainly to the growing incomes on a global scale, progressive urbanization, and increased access to electricity, i.e., with electrification. As for electricity alone, its consumption projects to increase by $79 \%$. In addition to the factors mentioned above, the population growth of our planet and the rising standard of living in many countries must take into account. The development of transport based on electric vehiclescars and railways-is also essential.

To better understand the thesis about the increasing energy demand, it is worth looking at historical data and seeing what the trend in energy demand looks like. Figure 1 shows that on the continents, where most economically developed countries (North America and Europe), the movement in energy use has been relatively constant over the last 30 years. What stands out is Asia, where the use of energy is increasing. In the remaining continents, we can also see an increase, but these are small about the continents mentioned above. Researchers' results indicate that there is a relationship between GDP and the level of energy used $[40,41]$, which is also confirmed in our research, only it was shown in a different context.

Figure 2 shows per capita electricity consumption in the division for each selected country. The figure shows that developing countries such as China, Brazil, and India are increasing their energy demand per capita. Governments of Western Europe and the USA have been in a somewhat declining trend over the last few years. Figure 2 shows a significant analysis. Brazil, China, and India, from the beginning of the 21st century, experience high economic dynamism and are the driving force of emerging markets. These countries respond for an enormous part of global energy growth. They coped with the economic crisis in 2008 much better than the USA or European Union. 


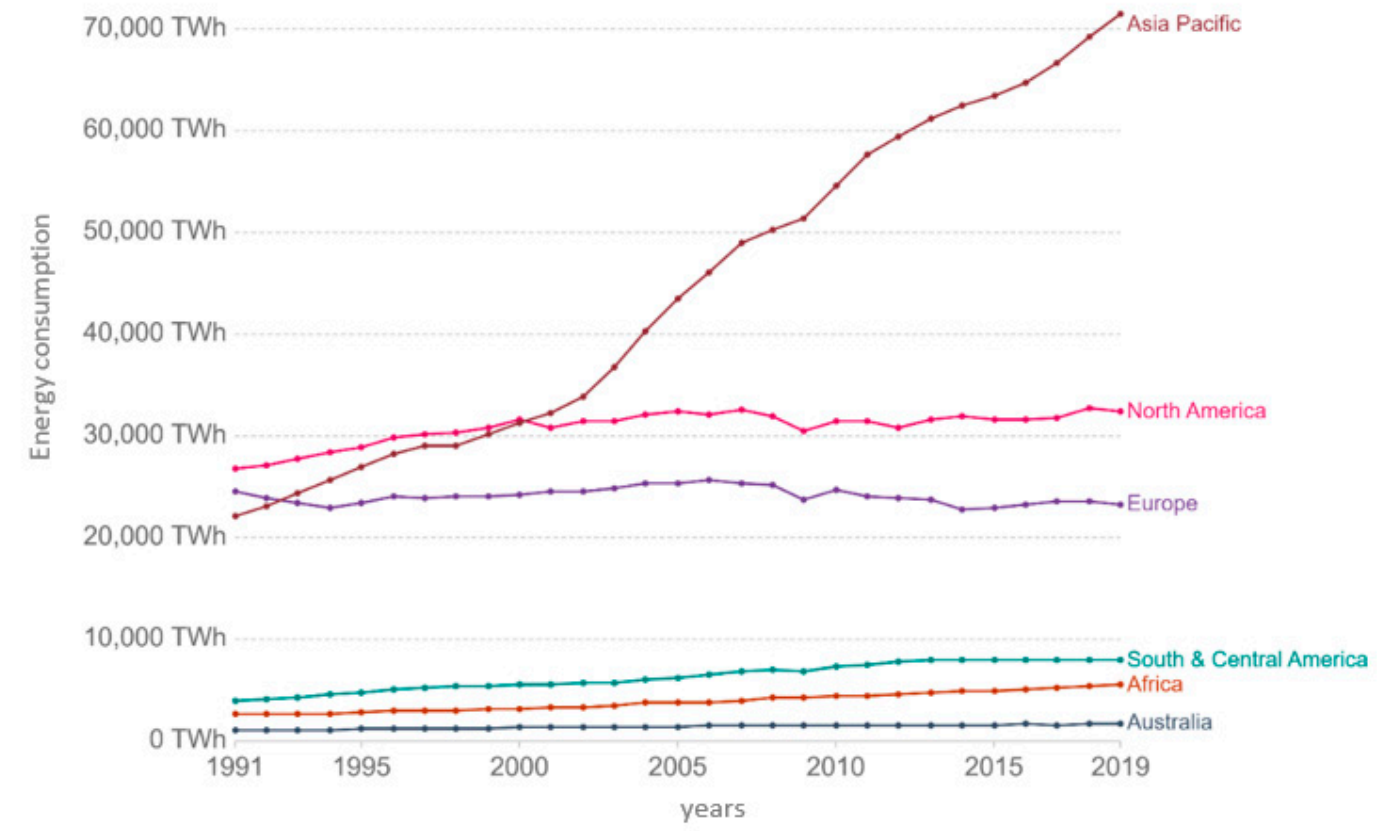

Figure 1. Primary energy consumption in terawatt hours (TWh)—world. Source: [1].

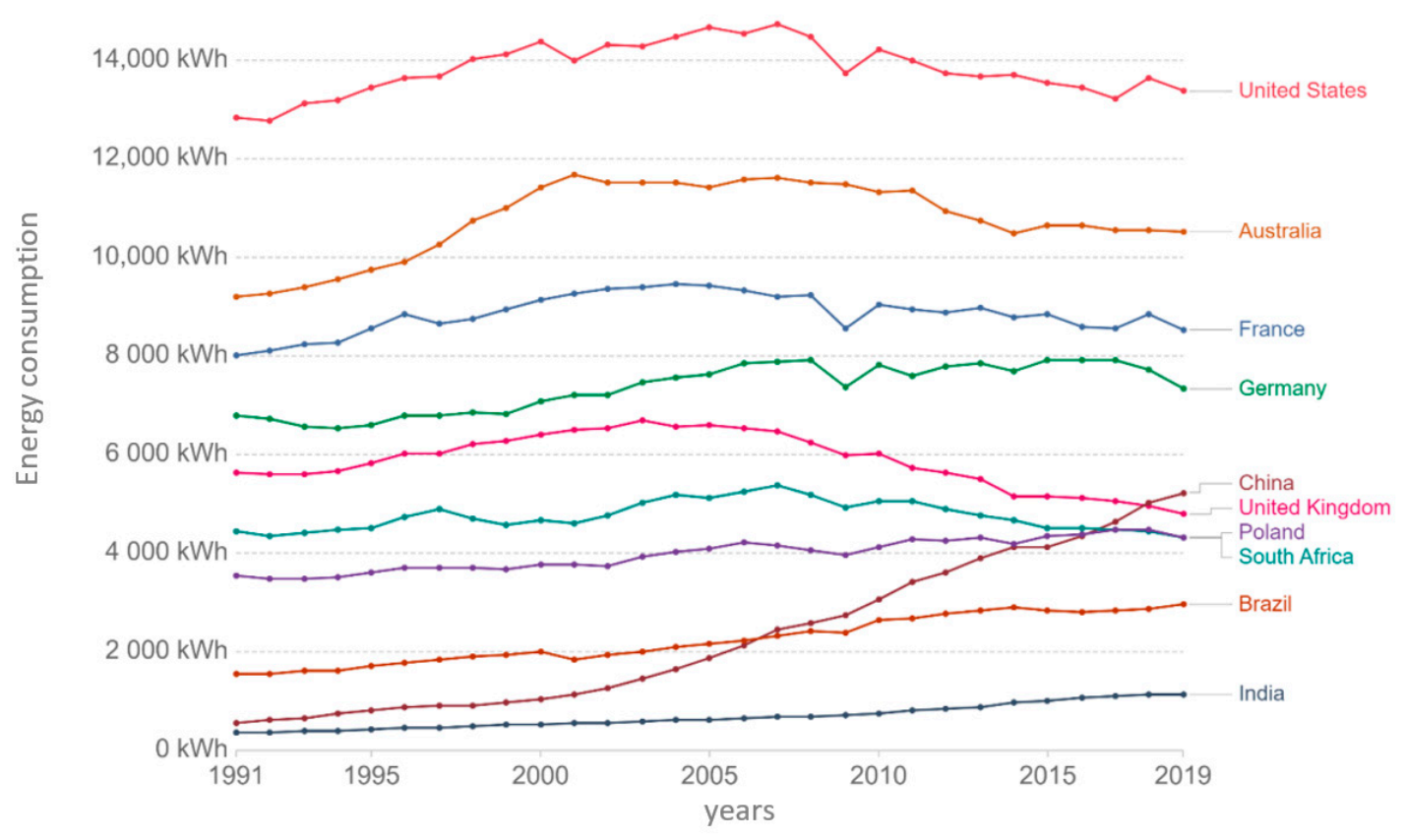

Figure 2. Per capita electricity consumption in kilowatt-hours (TWh)—selected countries. Source: [1].

The next chart (Figure 3) shows energy consumption in selected countries (Poland, Germany, United Kingdom) over the last 30 years. It can be seen that in the case of Germany and the United Kingdom, energy consumption has been decreasing in recent years. In Poland, it is relatively stable, although in recent years (from 2015), consumption has been increasing. There may be various reasons for the decrease in energy demand. The collapse (especially in 2008) in the European Union countries and the United States, as shown in the figure, is primarily due to the weak economic situation caused by the financial crisis and the associated lower demand for electricity in industry. A similar situation observes in 2020, e.g., in Germany, which is related to the ongoing global COVID 19 pandemic and its consequences of restrictions in various sectors of the economy. According to preliminary calculations of the BDEW [42], electricity consumption in the first half of 2020 in Germany 
was $5.7 \%$ lower than in the first half of 2019. It seems that this trend will be downward all over the world and not, as in 2008 and beyond, only in highly industrialized countries. Another reason for this state of affairs is climate change, mild winters in Europe, which cause lower energy demand. Germany has seen a large drop in energy consumption of several percent due to the slowdown in the economy due to the coronavirus epidemic and the increase in renewable energy production. It may result in Germany achieving its goal of reducing $\mathrm{CO}_{2}$ emissions by $40 \%$ in 2020 compared to 1990 levels. Simultaneously, it points out that even without the economic slowdown caused by the coronavirus, Germany would reduce its $\mathrm{CO}_{2}$ emissions this year-due to relatively high temperatures at the beginning of the year, better wind conditions, and lower gas prices [43]. The visible demand and consumption of energy are still reaching enormous values globally. The visible decreases are also a consequence of various administrative, legal, and conceptual measures. Cities, like industry, also have a massive energy need. Recalling the example of Germany, it can point out that since 2010 various types of plans (Masterplan) have implemented, which allow cities and municipalities, with their own resources, aid, or cooperation between local authorities and energy companies, to change their lighting to more energy-efficient, innovative and digital, supporting the idea of a smart city. Data and forecasts of the World Energy Council [44] indicate that about 10,000 MWh of energy per year need a town with nearly 1 million inhabitants to function safely and without problems. However, cities are developing very intensively. Each week, cities around the world are growing by an additional million inhabitants [45]. Global energy demand project to peak in 2030. By that time, cities worldwide will have grown significantly, and solve problems related to energy supply, electricity, and clean air will become an absolute priority. Another element indicating the increase in energy demand in cities and among the world's inhabitants is digitalization [46]. In addition to urbanization and industrialization, it is this very factor that causes the increasing demand for energy consumption by individual households. Despite the observable stabilization or decrease in energy demand, it is clear that without taking measures to save energy, the upward trend can maintain. It is important that in the era of depletion of conventional resources, on which the energy demand is based, measures should be taken that will prevent the increase in energy consumption, and the associated negative consequences, e.g., emission of pollutants into the atmosphere.

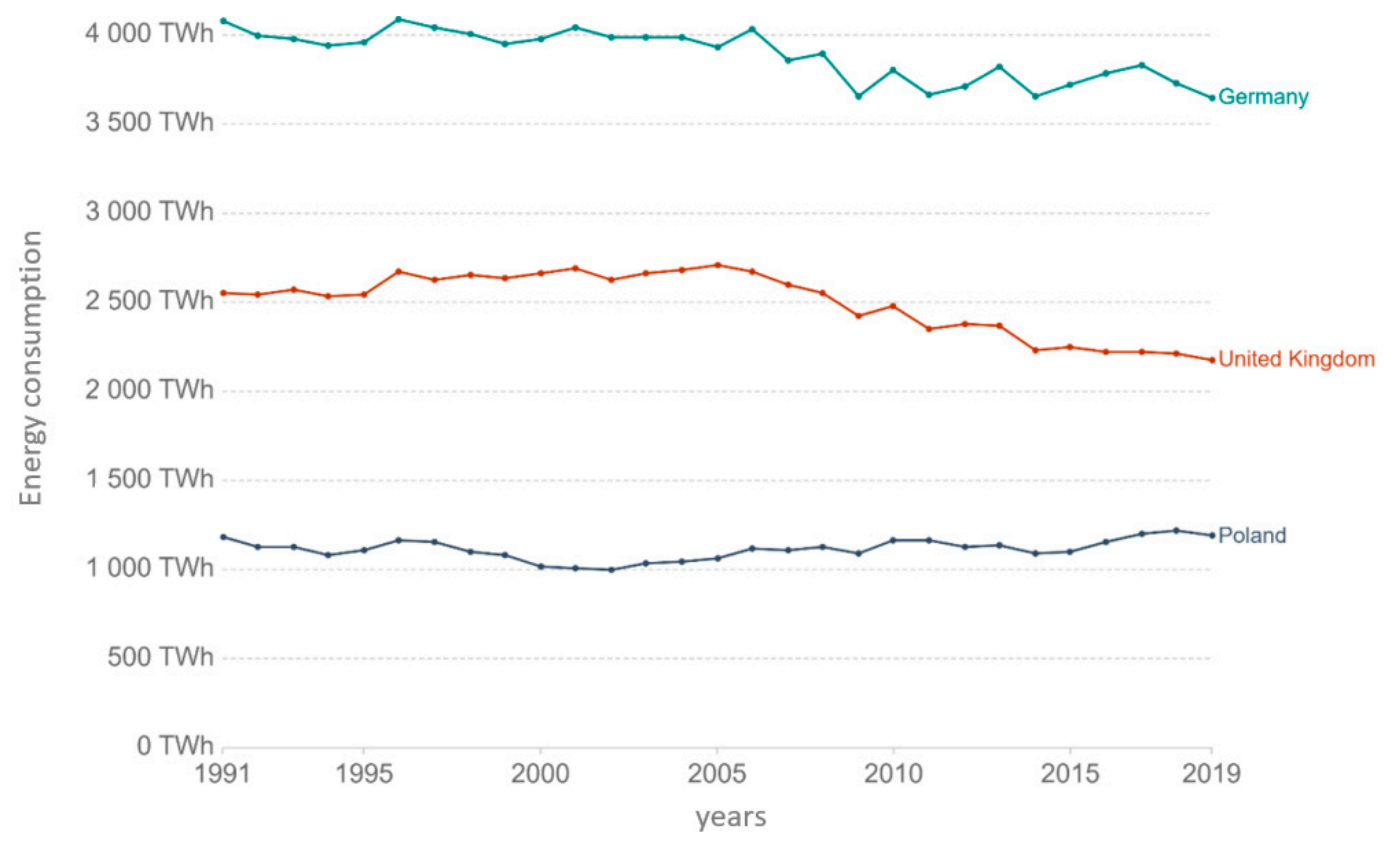

Figure 3. Primary energy consumption in terawatt-hours (TWh)—selected countries. Source: [1]. 
To analyze the energy consumption data of these countries more closely, Table 1 shows energy consumption but only from the public sector. Here you can see that again in Germany and the United Kingdom, consumption is relatively constant and even decreasing (from 2016). It can influence by the widespread use of LED technology in public space lighting. In the case of Poland, however, consumption is increasing. The increase in energy consumption in Poland is a sign of the development of the country's economy-energy increases, new companies are created, the demand for energy is greater. Poland, following the footsteps of European countries, should strive to separate the time of economic growth from electricity distribution. This will mean an increased rate of consumption but less than the rate of GDP growth. Additionally, it may be a sign that Poland is entering a period when GDP growth does not take any noticeably higher electric voltage. Moreover, Figure 4 shows energy consumption in the public sector in Poland with a forecast for the following years. It can see that consumption in recent years is increasing. If the trend continues, it will increase by about $4 \%$ per year (the forecast was applied using a polynomial trend). The graph also shows a prediction of energy consumption when we assume that Poland will start using LED technology (in public services) -an assumption of $10 \%$ replacement of lamps in general lighting every year, giving savings of about $20 \%$ in this area.

Table 1. Energy use in commercial and public services (selected countries).

\begin{tabular}{cccccccccc}
\hline TIME & $\mathbf{2 0 1 0}$ & $\mathbf{2 0 1 1}$ & $\mathbf{2 0 1 2}$ & $\mathbf{2 0 1 3}$ & $\mathbf{2 0 1 4}$ & $\mathbf{2 0 1 5}$ & $\mathbf{2 0 1 6}$ & $\mathbf{2 0 1 7}$ & $\mathbf{2 0 1 8}$ \\
\hline Germany & 143,862 & 136,306 & 139,210 & 142,062 & 131,515 & 140,736 & 141,585 & 141,479 & 137,097 \\
\hline Poland & 43,669 & 44,190 & 44,378 & 43,130 & 45,171 & 45,443 & 47,800 & 47,019 & 49,441 \\
\hline United Kingdom & 97,372 & 95,718 & 96,802 & 97,652 & 93,356 & 94,144 & 93,692 & 92,792 & 92,257 \\
\hline \multicolumn{7}{c}{ Source: $[47]}$. &
\end{tabular}

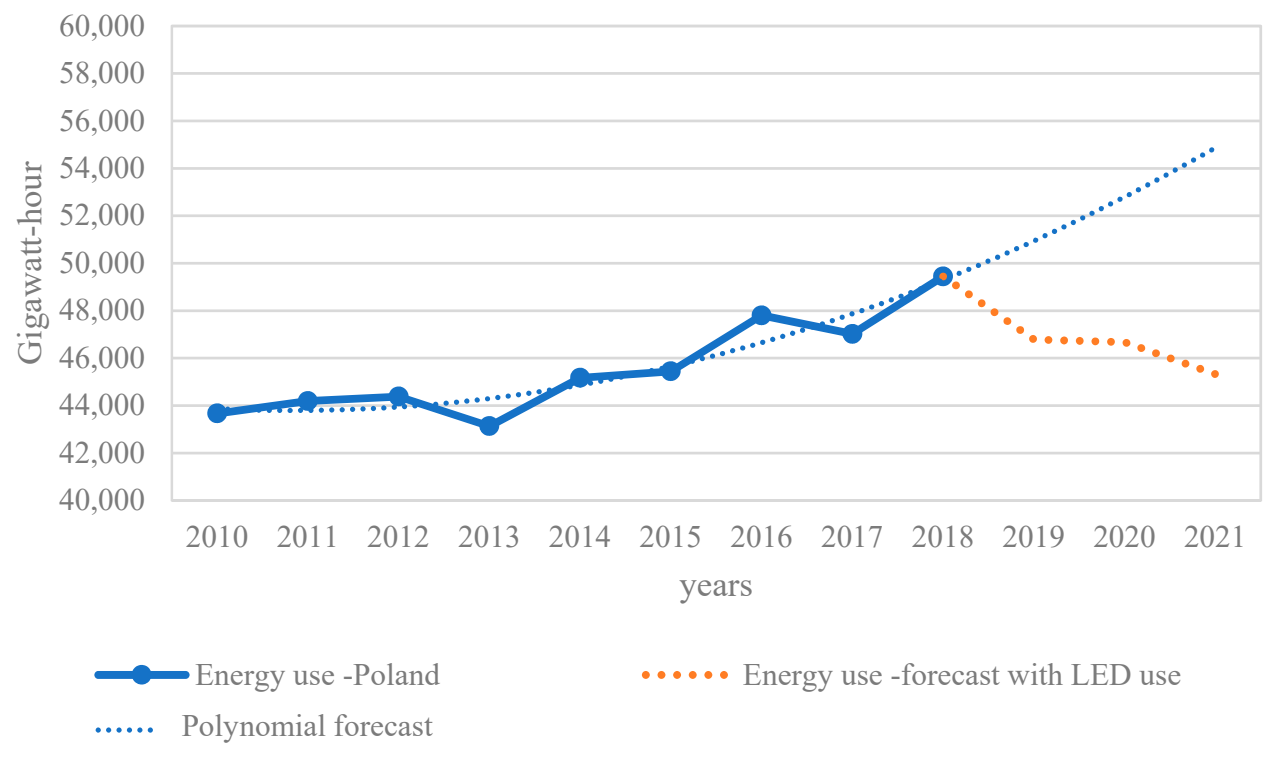

Figure 4. Energy use in commercial and public services with forecast-Poland. Source: [48].

The next graph in Figure 5 shows another unfavorable trend that has persisted in Poland in recent years-expenditure on street lighting in municipalities. It can seem that over the last 20 years, with small interruptions, prices have been constantly increasing. There may be several reasons for this situation. First of all, energy expenses are rising because most of the infrastructure is outdated, requiring modernization, and the lighting itself, e.g., sodium, is not sufficient. The expenditures on the modernization of lighting infrastructure are associated with investment expenditures. Still, as the examples (case studies section) show, they pay for themselves in a concise period, allowing for savings related to the energy consumption expenditures alone. 


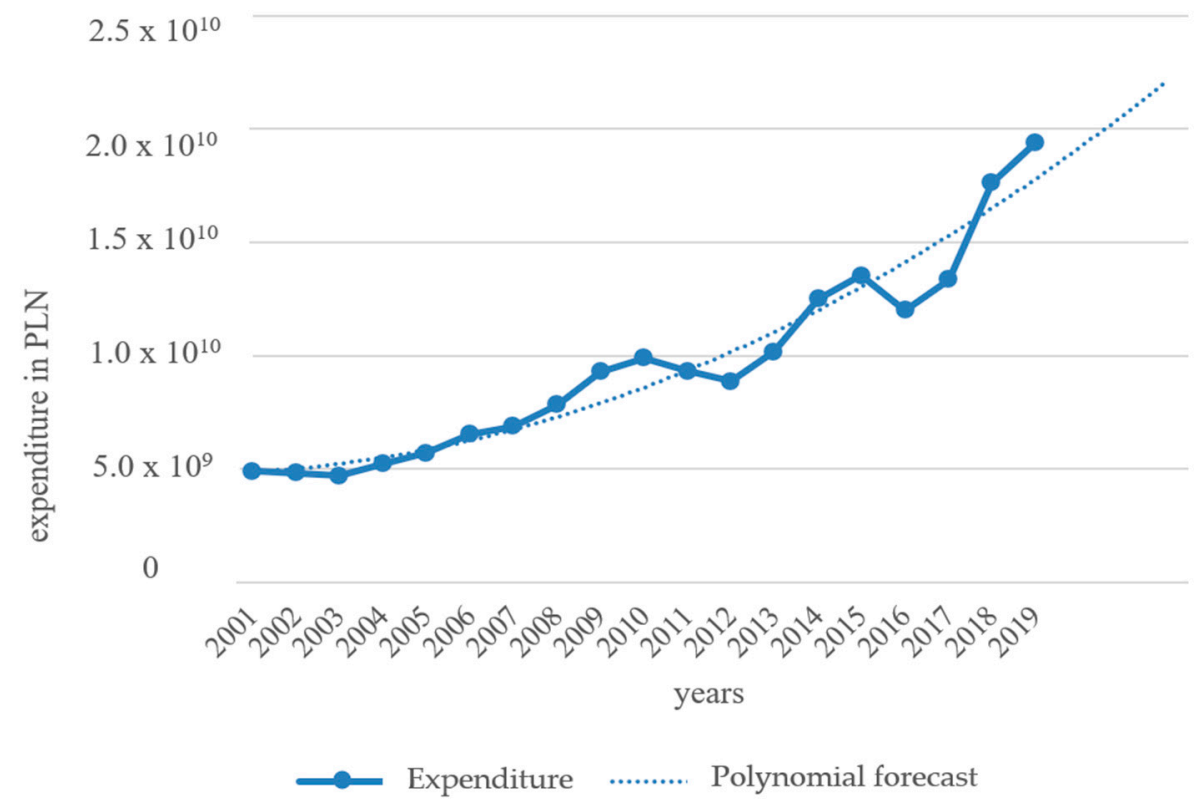

Figure 5. Expenditure on street lighting for municipalities in Poland. Source: [48].

Currently, energy consumption is much greater than several dozen years ago. Calls are being made to all sides to save it. What is more, we are becoming increasingly aware that saving energy is very important not only for our wallet but also for the environment. Therefore, energy efficiency is becoming an important criterion for smart cities [49].

\subsection{Smart Lighting}

Smart lighting is an important element of energy management as part of the smart city concept. Smart lighting encompasses a heterogeneous area of lighting management, which offers the possibility of integrating a wide range of techniques and technologies into the ideas develop concepts. It is no longer just lighting associated with a streetlamp but a device that allows the installation and use of information and communication technologies to achieve the most excellent possible efficiency and reduce negative environmental impacts. The intelligent lighting network enables access to additional data in real-time. In this aspect, it is possible to talk about small individual elements, such as spot air pollution, traffic, and volume monitoring, using a holistic approach involving the management and monitoring of the entire urban ecosystem [50]. The multifunctionality of intelligent lighting allows the integration and use of these resources as light sources, relays, weather stations, air pollution recorders, or electric vehicle chargers. Modern lanterns have electronic systems that allow the control and monitoring of various processes [51] in support of urban intelligent services. Currently, the technological advancement of solutions using LED (Light Emitting Diodes) allows not only energy savings due to the technology of the source itself but also for the development, integration, and use of advanced lighting systems and functions. It allows for high efficiency and responsible use of infrastructure. Smart lighting creates intelligent functions as well as interfaces for lighting solutions in the ambient, commercial and public domains [52] for management using the Internet of Things (IoT). LED smart lighting can be a significant catalyst for the evolution of IoT, supporting the rapid development of the smart city concept globally. Monitoring, storage, processing, and data analysis systems enable comprehensive optimization of the entire installation and monitoring of municipal lighting systems based on various parameters. Modern management of an outdoor lighting system is possible from one central point, and technological solutions allow both the whole system and each luminaire or lantern to be managed separately [53].

Intelligent lighting integrates intelligent functions and interfaces on four levels that complement each other $[52,54,55]$ : 
- First level or levels built into the lighting engine or the light source itself.

- The second level or levels of the electrical system in luminaires and lighting systems.

- The grid level or level includes end-to-end management and real-time monitoring of energy sources, power plants and utilities along with distribution facilities.

- The fourth level or level of communication and detection is incomplete lighting technologies along with applications and programs for monitoring, control and management.

Such a system requires appropriate optimization. Among other things, it bases on designing it in such a way as to find the most effective technical parameters and their combinations to obtain the best results. The parameters influencing the above factors may be the height of the lighting units, their inclination or the distance between the columns [56,57]. It is a very useful system due to the location, density, and availability of lighting lamps.

LED lighting can be used as a platform for intelligent urban services. Being part of a smart city allows for:

- reducing energy and infrastructure maintenance costs.

- increase public safety through a better, more efficient, and dynamic street lighting system adapted to outdoor conditions, including the use of cameras.

- $\quad$ safer movement, better visibility of risks.

- protection of the environment, due to lower emissions of harmful substances into the atmosphere $\left(\mathrm{CO}_{2}\right.$, emissions, and noise), including the reduction of energy use.

- ensuring the right amount of light, the right time, and the right place. Such a solution is possible, among other things, through the implementation of lighting schedules that automatically adjust the operating time and light intensity to the real needs of residents.

- the use of infrastructure for mobile broadband communications.

- being traffic light controller.

- supporting intelligent car parks.

- $\quad$ support for traffic management.

- be part of an electric vehicle charging station (EV).

- seismic registration in case of earthquakes.

- installation of emergency telephone boxes.

- the longer service life of this type of luminaires.

Advanced LED lighting solutions (including efficient use of luminaires) include integration with cloud computing to deliver real-time data to central servers. It provides real-time information on movement, temperature, brightness, and air pollution. Integration with the relevant application allows the monitoring of different parameters of the urban system Luminaires installed in pedestrian areas work in synchronization with motion sensors, which ensure that the lamps do not shine with full force when no one is near them. Each of the luminaires can be remote-controlled, and data on the technical condition of the infrastructure is also transmitted to the system on an ongoing basis, thanks to which any faults detect almost immediately.

There is a lot of research in the literature on street lighting that focuses on operational and strategic levels. The functional level allows to present in real-time ways to improve the effectiveness of implemented systems (including methods of lamp control and control) [58], adaptive on-demand energy-based street lighting control, and, e.g., traffic forecast [59], up to actions at the strategic level including integrating smart lighting with traffic management within the intelligent urban platform [60] or power diversification and use of renewable energy. At the strategic level, including in smart cities, the LED street lighting program is combined with a central management system (CMS), using IT networks and communication technologies. With all these functions, lighting in the city can manage more efficiently and wisely. Decisions do not make based on estimates but based on specific data that are continually flowing into the system from the intelligent sensors installed in each luminaire [28]. 


\subsection{Smart Energy as a Part of Smart City Concepts}

The smart city concept is an innovative idea whose goal is to manage the city and its resources in an ecological, modern, economical, and practical manner. New urban areas are continually developing their innovative technologies, primarily information and communication technologies [61]. The concept of smart cities also relates to many other fields, such as energy, architectural engineering, environmental protection, transport engineering, knowledge, and innovation management, social sciences, and e-administration.

One of the fastest-growing forms of settlement in the world are cities where problems related to the growing number of people and population density can observe. Population growth in smart cities has increased demand for buildings, infrastructure, and energy supplies in urban areas. City authorities face the challenge of introducing sustainable energy systems related to the energy transition and transition to a low-carbon society [62]. It becomes necessary to use renewable energy sources and implement efficient technologies in the field of energy infrastructure and urban infrastructure, such as [63]:

- Smart Meters-real-time energy, water, and gas measurements, including energy consumption measurement,

- Smart Grids-redesign of electrical systems through the use of smart meters, smart devices, and renewable energy sources to achieve better energy efficiency,

- Smart buildings - a range of sensors and technologies that improve safety, security, energy efficiency, and usability in urban construction,

- Electric vehicles - cars powered by electricity and batteries, providing adequate infrastructure for charging vehicles throughout the urban area,

- Smart Parking - car parks and parking locations on the street, real-time information transmission to users,

- Smart LED Street lighting-light sensors and communication devices that enable communication of lights with other nearby lights and control at the city level, and replacement of traditional street lighting with energy-saving and environmentallyfriendly LED lighting.

The concepts of smart cities and smart environments, as well as related technologies, are gaining increasing importance [64]. The everyday basis of energy transformation and a smart city is data from ICT [65]. The use of modern tele information technologies in the energy sector brings real benefits to smart cities in the form of lower costs of street lighting.

It is due to the implementation of a city lighting system based on new LED lighting fittings control using an intelligent control system via the Internet, thanks to which data is accessed at any time and anywhere.

The luminaires are equipped with traffic flow detectors and weather sensors, which enable the selection of the appropriate lighting control algorithm depending on the weather and the current traffic situation.

\subsection{Case Studies}

Intelligent lighting solutions support by many local, national, or global initiatives. Since 2011, The Climate Group's Lightsavers [17] initiating the change of lighting on LEDs in 12 global metropolises. The potential for lighting change is enormous, as there are over 300 million upgradeable streetlight points, growing to 352 million by 2025, smart led systems will cumulatively represent EUR 51,9 billion market opportunity [16]. It is also crucial that the solutions are not just about replacing luminaires or light bulbs. These must be systemic solutions, including an inventory of contemporary lighting, the bulbs themselves, the poles, cables, and all supporting infrastructure. The potential for energy savings is enormous. Analyzing the plans of individual countries or urban units, one can see an interest in the subject and, despite the necessity to incur high costs, great interest in implementing the concept.

As part of the national program to replace lighting with greener and more efficient, India has planned to change 35 million streetlights and 770 million light bulbs to LED by the end of 2020, saving EUR 4.9 billion a year by reducing electricity consumption. 
The installation of 1 million LED streetlights has resulted in annual energy savings of 6.71 billion $\mathrm{kWh}$ and avoided $1119.40 \mathrm{MW}$ of peak energy demand, resulting in a reduction of 4.63 million tons of $\mathrm{CO}_{2}$ emissions per year [66].

Many cities have participated in the program. Some of the initiatives have already complete. Some are still ongoing. One of the participating cities was Adelaide, which participated in the project in 2009-2012. The main advantages of the successful project were better (4 times higher) light intensity offered by LED lamps, a reduction in energy consumption of $18.4 \%$ (assumed 18\%), and increased efficiency in directing light to the surface of the pedestrian path. The project replaced 4800 lamps (which represents $10 \%$ of public lighting). The solution will reduce $\mathrm{CO}_{2}$ emissions by $50 \%$, by 1300 tons per year [17]. Pilot projects have been implemented in Hong Kong under the same program relating to LED lighting. Solutions were applied, among others, at the campus of The Hong Kong University of Science and Technology (HKUST). The project, which ran for 19 months in 2010-2011, installed LED lamps on the campus and on the way to the campus. The Seafront Driveway, where the new lights are installed, usually illuminated $8.5 \mathrm{~h}$ per day. Lighting from three manufacturers was used. The second project was implemented at The University of Hong Kong, the lamps were installed on a section of road which is accessible to pedestrians and cars. The pilot period was 11 months. At the time, four LED luminaires were installed, and the distance between them was $20 \mathrm{~m}$. The project was carried out in 2010-2011. The energy-saving results for HKUST were between $67 \%$ and $78 \%$, compared to traditional luminaires. For HKU, the level of energy savings was $89 \%$ compared to conventional lighting. Pilot projects have also been implemented in New York. One of them included the implementation of LED lighting in Central Park. The project started in 2009 and was completed in 2012. The pilot program consisted of examining, through independent performance tests, more than 500 luminaires, which represented 27 different LED products available at the time. The most important conclusions after this pilot study are that LED lighting achieves savings of between $50-70 \%$ and even up to $80 \%$ when combined with intelligent control. Even the installation of such luminaires locally brings benefits compared to standard luminaires. A positive effect is the long service life of such lighting, with small changes in light intensity and color. The second project was to change some of the lighting to FDR Drive. It was the first step in changing lighting on New York City freeways. The project also started in 2009. 24 lamps were installed, and a period of around one year was spent carrying out tests of the performance of the new lighting. The conclusions of the piloting are similar to those of other projects, with savings of between $15 \%$ and $50 \%$. A similar project was implemented in Sydney. The pilot was implemented in a business district and compared with traditional lighting. The results of the pilot project were satisfactory, therefore, in 2011 a contract was signed for the installation of LED lamps in 6448 buildings in the city. By 2015, 1500 existing luminaires were replaced. Similar results were achieved by pilot projects in other cities such as Toronto, Birmingham, and Madrid. Other examples of integration with smart city concepts are presented in Table 2.

Table 2. Examples of integrating outdoor LED lighting with smart city concepts.

An integral part of Manchester's "smart city" program is a large-scale program for replacing street lighting-with LED lamps. The program has been completed in three years, and 56,000 luminaires have replaced.

Manchester The new LED system will achieve 60\% efficiency savings compared to traditional lamps, allowing the city to save (United around (EUR 2.3 million) per year on energy costs and reduce the city's carbon footprint by 7500 tonnes per year Kingdom) Besides, the lighting will be controlled remotely, through integration with the city's monitoring system (CMS). Additionally, light sensors use to monitor air quality and traffic flow cooperation between the city, businesses, academic institutions, and service providers.

The LED modernization program in Cardiff included the installation of 14,000 LED street lighting luminaires. It is to bring about $60 \%$ energy savings. The estimated financial savings are (EUR 855,000) per year. All 14,000 lamps will be connected wirelessly to a centralized management system (CMS), which allows city managers to monitor and control lighting assets remotely, and provide advanced operational analysis to optimize savings further. 
Table 2. Cont.

One of the first cities to use LEDs on a large scale was Los Angeles. The replacement of street lamps with LED lighting started in 2009. To date, the city has equipped 180,000 lamps with LED luminaires, achieving 65\% energy savings, equivalent to EUR 8.17 million per year in cost savings and 65,000 tonnes of $\mathrm{CO}_{2}$ equivalent per year.

The system connects to the CMS - City Management System. In 2015, the city started, implementing the "intelligent city" concept, the installation of 100 smart poles, which integrate LED lighting and 4G LTE wireless

Los Angeles (USA) connectivity. It allows the city to expand its broadband Internet network without having to build more mobile towers. By the end of 2020, an additional 500 smart poles are to be installed. Various monitoring systems and sensors have been piloted on street lamps to investigate environmental factors (noise, traffic, and pollution). Los Angeles is saving around EUR 8.17 million per year in electricity costs after switching to LEDs. A further EUR 2.45 million in maintenance savings. Increasingly companies are saving $50-70 \%$ of their energy use through connected LED lighting - and up to $80-90 \%$ when linked to sensors, smart controls, and the Internet of Things (IoT) technologies.

An essential element of the program is to achieve carbon neutrality by 2025 . The main factor of the "Smart city" Kopenhagen initiative was installing 20,000 connected LEDs for street lighting. It leads to energy savings of $65 \%$. LED street (Denmark) lamps equipped with intelligent modules, which use to increase the safety of cyclists. When the modules detect a cyclist, the lights become brighter when the cyclist approaches an intersection. The lights dim when no one is nearby, and reducing light pollution.

Jakarta

(Indonesia)

More than 90,000 street lights in the city are equipped with a LED lighting system. It is one of the largest systems in the world (energy savings of $70 \%$ ). The lighting system is integrated with other smart city systems and enable the city to remotely manage lighting and adjust its level to the needs of each district.

Buenos Aires wants to modernize over $70 \%$ of street lighting to LED diodes. There are 126,000 city luminaires in the city. 55\% was replaced with LEDs. The new system allows you to monitor the light level. Due to the

Buenos Aires

(Argentina) introduced changes, the luminous flux will decrease. It will also lead to an increase in savings from an estimated $50 \%$ to $80 \%$ compared to HPS.

London

(United

Kingdom)

There are approximately 52,000 local street lamps in London. As part of the program to switch to LED street lighting in the London network, 35,000 lanterns will be replaced by 2022/23. Total cost of the LED price to around EUR 11.98 million. It estimates that the payback period will be less than 10 years. Most, if not all, of the remaining 17,000 street lamps update within ten years. London also monitors air quality using sensors attached to the lighthouse as part of the Connected London program.

Since 2013, the Land Transport Authority (LTA) has started implementing energy-saving light-emitting diodes (LED) for street lamps in Singapore. LED street lighting is approximately $25 \%$ more energy efficient than current street lighting, is more reliable, and requires less frequent replacement. Since 2014, LTA has installed LED lighting in around 29,000 street lamps, while in the remaining areas, traditional street lighting will replace by LED lighting by 2022. An essential element is the introduction of Remote Control and Monitoring (RCMS) for illumination to enable the system to better respond to changes in weather.

Chicago launched its smart lighting program in 2017. It expects to support more than 270,000 obsolete high-pressure sodium (HPS) luminaires using energy-saving LEDs. The city estimates it will save around EUR

Chicago (USA) high-pressure sodium (HPS) luminaires using energy-saving LEDs. The city estimates it will save around EUR
8.17 million each year. The higher quality of light provided by LED technology will improve visibility and safety,
create a modern lighting management system to facilitate maintenance and repair.

Chicago (USA)
8.17 million each year. The higher quality of light provided by LED technology will improve visib
create a modern lighting management system to facilitate maintenance and repair.

It is the largest urban LED installation project in Europe. It covered 90 thousand street lamps. The expected energy savings are 50\%, reducing annual running costs by EUR 2.2 million. The higher upfront costs incurred about intelligent control are fully offset by lower energy consumption and lower maintenance and replacement costs. An effective public lighting strategy has implemented. A real-time monitoring system has introduced that collects data on the system performance. It is possible to vary the intensity of light intensity depending on the current needs. This will lead to a significant reduction of energy consumption.

The digital master plan for lighting, which is the result of cooperation between various ministries and local government units, and an energy company, was implemented in the city of Cologne (Germany). The initiative involves developing a strategy for efficient, digitalized night-time city lighting. The program manages the lighting and dynamically integrates historical data, which is supplemented with up-to-date information. In this way, the lighting parameters determine modernization and future investments. It is to serve as an element of urban energy planning and management. The concept is not only about energy saving but also about lighting efficiency. It reduces the undesirable 
phenomena of degradation of the night image, as it often happens during the modernization of lighting-replacement of discharge lamps for ill-suited LED luminaires_-based mainly on the criterion of energy-saving, illumination of the roadway without sufficient analysis of the structure of the urban tissue, creating random light spots, under-lighting of vertical urban space, which is primarily responsible for the feeling of safety and contrasting or unjustified divisions of space. The lighting of all the most important buildings has planned in such a way as not only to emphasize their unique architecture but also to find an appropriate place in the urban structure of the city and create landmarks and highlight the planned visual axes. The idea of a digital master plan met the need for a lighting design more suited and focused on the needs of cities and a rapidly growing market [70].

In Poland currently, only 10\% of all street and park luminaires in Poland are energyefficient LED luminaires. The remaining $90 \%$ are usually outdated and extremely energyintensive mercury, sodium, and metal halide lamps [71]. This state of affairs means high costs of electricity. It is the result of using ineffective and outdated lighting technologies in cities.

Solutions are becoming increasingly popular. For example, it points out that Szczecin, together with Philips Lighting, has replaced nearly 5 thousand lamps in the city center with energy-efficient LED lighting. It resulted in annual savings of EUR 333,805 and a reduction in carbon dioxide emissions of 2.7 thousand tonnes per year. Along with the replacement of luminaires, an intelligent system for managing city lighting was also implemented. This system is to be an element of the smart city and integrates with other smart platforms and IoT devices. With the new luminaires, savings are estimated at $70 \%$. Replacing old luminaires with LEDs alone could reduce electricity expenditure by $50 \%$. In Szczecin, after the modernization of lighting in the city center, $\mathrm{CO}_{2}$ emissions were reduced by 7000 tonnes per year. And 'only' 7000 of nearly 30,000 luminaires replaced.

By the end of 2022, Warsaw will replace 38.5 thousand streetlamps that will use LED lighting. These lamps will be specially designed for the needs of the city so that they can connect with the integrated lighting management system in the city. It is the largest investment of this type in Poland. A total of 43,000 lamps will replace. The new LED lighting on the streets of Warsaw will be brighter, and safer, and more environmentally friendly. It has been estimated that such modernization will reduce the cost of electricity three times, which will save about 38 GWh, i.e., the amount of about (EUR 4 million) per year. It means that energy savings alone will allow the return-on-investment costs within three years [72].

\section{Discussion}

Currently, 1.6 billion people still have very limited or no access to electric light [73]. So, when the sun goes down at the end of the day, the possibility of any social, cultural, or recreational activity disappears with it [74].

The future of a smart city includes intelligent lighting solutions in public space $[75,76]$. The priority goal of smart cities is to build urban infrastructure, taking into account energy plans for street lighting $[77,78]$. Initially, it should be started by creating a comprehensive street lighting management system [79]. New communication technologies carry data. Their implementation will improve the city management system, which will result in an improvement in the quality of life of city inhabitants $[80,81]$. The next step is to create an interactive public space where appropriate lighting applications combined with modern technologies will create a friendly place for residents and activate local business [82].

The reduction of electricity consumption for lighting purposes is implementing during the modernization of roads, often accompanied by the completion of lighting points and the construction of new road sections [83]. Because that the number of new lighting points is growing, the electricity savings compensate for the increase in energy consumption in new lighting points [84].

The need to move towards a low-carbon economy and to reduce energy consumption, particularly in cities, makes it necessary to take action to achieve these goals [85]. There 
is a growing interest in this topic in scientific publications. Recent research focuses on how to optimize the consumption of street lighting [46], which is consistent with the solutions already presented (case studies), technological innovations are also implemented, including [86]. Much attention is also given to aspects of general energy supply and modern solutions [87]. Research that focuses on the aspect of modern and intelligent energy also refers to the modern use of already known technologies (e.g., LED) [88] or the use of industry 4.0 and big data solutions in this field [89]. New business models are also emerging that no longer just offer basic pillars and changes to them (e.g., lighting) but take a more comprehensive approach to research topics [90]. An energy-smart city using smart technologies can become a variant of a low-carbon city. It can therefore be seen as a combination of smart cities and low-carbon cities [91]. Both strategies and concepts of modern cities are supported by, among other things, the indicated smart lighting solutions. The indicated examples of implementations clearly indicate that smart lightening solutions fulfill more than one economic, as well as social, and environmental goals. The economic objectives will be related to the reduction of costs incurred for urban lighting, while the social objectives are identified with a higher level of quality of service, better lighting, greater safety, less unreliability of the infrastructure, and modernity. Environmental objectives are related to greater environmental neutrality, less pollution, and lower energy consumption. The indicated case studies are good benchmarks and examples of what other cities can do to be smart using modern lighting.

\section{Conclusions}

The adoption of intelligent lighting solutions contributes to lower energy consumption and thus leads to savings. The savings indicated can be measured and justified using appropriate indicators (e.g., energy performance indicators for road lighting systems [92]. Their use confirms the cost-effectiveness of the indicated solutions. The introduction of optimal solutions, including dynamic lighting management, supported by IT tools of the lighting management system increases the reliability and efficiency of smart lighting applications while gaining the approval of all stakeholders of the urban space [93]. The choice and selection of an appropriate performance measurement system can be crucial for the future of implemented concepts. The use of energy efficiency indicators and the optimization of LED lighting in cities is one of the criteria for the success of a concept and for convincing its implementation.

All these benefits are measurable. However, there is also another aspect, the installation of intelligent lighting. High-quality, intelligent lighting increases the abstraction of a structure, land, building, or city. Therefore, cities should use efficient, intelligent lighting as an element of changing the city's aesthetics (light illumination of buildings) and pointing out new landmarks. Such factors contribute to economic growth and lower expenses while achieving positive effects from user friendly, economically efficient lighting.

LED lamps have become efficient, long-lasting, environmentally friendly, and fully controllable, opening up a whole new area of possibilities in building lighting systems. In the last ten years, technological advances have reached almost the speed of light [94]. The resulting solutions enable fascinating lighting of different spaces and shaping various moods using intense white or colored light. All this with energy consumption is only a fraction of the energy needed by conventional systems.

But LED lights are not only about aesthetics. This technology is extremely energyefficient-it generates white light of uniformly high-quality brightness and intensity with up to $70 \%$ lower energy consumption [95]. LED lamps also have extremely long durability, making it possible to eliminate most of the service work and maintenance required with traditional lighting systems. They are ready-to-use, future-proof solutions, the purchase price will pay off more than once while the fittings are in use.

The current environmental awareness and knowledge about the impact of greenhouse gases on the functioning of the entire planet allow us to notice a high share of public space lighting in the city's energy bills, approx. 40\% of total energy expenditure. Equipping 
lighting systems with remote management devices would reduce these costs by half. Europe is proving to be the most effective region so far in combating climate change and implementing the energy transformation. The growth of energy demand in the European region has been much lower than in the rest of the world. Germany is leading the way in this area, with the largest drop in demand of $2.2 \%$. It is made possible by implementing various concepts, including smart cities and supporting the smart energy component. Actions are taken in multiple fields, in the industrial sphere, at the level of cities, or directly related to citizens.

Cities face continuous pressure to meet their energy reduction targets, and at the same time, have an obligation to provide lighting that complies with different standards. Roads connecting residential areas with crowded expressways or industrial zones require special lighting that considers the needs of both pedestrians and motorized users. LED lights that combine functionality with ambiance are ideal for this purpose. On the one hand, they offer the technical advantages of traditional road lighting systems and, on the other, a friendlier atmosphere suitable for places with many people.

The analyzes presented in the article show that in most countries the energy demand has been falling in recent years or has remained relatively stable. The reason for this situation is found in the economic downturn caused by the financial crisis and the related lower demand for electricity in the industry in 2008, while in 2020 a decrease in energy demand may be the result of the ongoing Covid-19 pandemic and restrictions introduced in various economic sectors in individual countries. Another reason is climate change (mild winters in Europe, better wind conditions) and lower gas prices. Smart city authorities are looking for solutions that bring savings in energy expenditure, including changing street lighting to more energy-efficient, innovative, and supported ICT technologies. The consideration presented positively proves the hypothesis and research questions posed. Despite the need to incur high infrastructural costs associated with the modernization of street lighting, external costs are reduced, and positive effects appear in the form of the implementation of sustainable development principles in urban spaces. Additionally, the cities implement innovative solutions and become the best examples and model projects for others.

Author Contributions: The following statements should be used: conceptualization, methodology, validation, formal analysis, investigation, resources, writing —original draft preparation, writingreview and editing, visualization-K.H.B., B.T., E.P., T.W., A.M. All authors have read and agreed to the published version of the manuscript.

Funding: The project is financed within the framework of the program of the Minister of Science and Higher Education under the name "Regional Excellence Initiative" in the years 2019 - 2022; project number 001/RID/2018/19; the amount of financing PLN 10,684,000.00.

Conflicts of Interest: The authors declare no conflict of interest.

\section{References}

1. Looney, B. Full Report-BP Statistical Review of World Energy 2020; BP: London, UK, 2020.

2. Zissis, G. Energy Consumption and Environmental and Economic Impact of Lighting: The Current Situation. In Handbook of Advanced Lighting Technology; Karlicek, R., Sun, C.C., Zissis, G., Ma, R., Eds.; Springer: Cham, Switzerland, 2016 ; pp. 1-13.

3. Rabe, M.; Streimikiene, D.; Bilan, Y. EU Carbon Emissions Market Development and Its Impact on Penetration of Renewables in the Power Sector. Energies 2019, 12, 2961. [CrossRef]

4. World Energy Outlook 2020. Available online: https:/ /www.iea.org/reports/world-energy-outlook-2020 (accessed on 16 December 2020).

5. The Climate Group. Annual Report and Accounts 2018/19; The Climate Group: London, UK, 2019.

6. Drozdz, W.; Miskiewicz, R.; Pokrzywniak, J.; Elzanowski, F. Urban Electromobility in the Context of Industry 4.0; Wydawnictwo Adam Marszalek: Torun, Poland, 2019.

7. Pfenninger, S.; Keirstead, J. Renewables, nuclear, or fossil fuels? Scenarios for Great Britain's power system considering costs, emissions and energy security. Appl. Energy 2015, 152, 83-93. [CrossRef]

8. IPCC Report. Energy Technology Perspectives. Scenarios E Strategies to 2050; ODCE: Paris, France, 2008. 
9. Kanniche, M.; Gros-Bonnivard, R.; Jaud, P.; Valle-Marcos, J.; Amann, J.M.; Bouallou, C. Pre-combustion, post-combustion and oxy-combustion in thermal power plant for $\mathrm{CO}_{2}$ capture. Appl. Therm. Eng. 2010, 30, 53-62. [CrossRef]

10. Maroušek, J.; Bartoš, P.; Filip, M.; Kolář, L.; Konvalina, P.; Maroušková, A.; Zoubek, T. Advances in the agrochemical utilization of fermentation residues reduce the cost of purpose-grown phytomass for biogas production. Energy Sources Part A Recovery Util. Environ. Eff. 2020, 1-11. [CrossRef]

11. Mardoyan, A.; Braun, P. Analysis of Czech subsidies for solid biofuels. Int. J. Green Energy 2015, 12, 405-408. [CrossRef]

12. Maroušek, J. Novel technique to enhance the disintegration effect of the pressure waves on oilseeds. Ind. Crops Prod. 2014, 53, 1-5. [CrossRef]

13. Bilan, Y.; Streimikiene, D.; Vasylieva, T.; Lyulyov, O.; Pimonenko, T.; Pavlyk, A. Linking between Renewable Energy, $\mathrm{CO}_{2}$ Emissions, and Economic Growth: Challenges for Candidates and Potential Candidates for EU Membership. Sustainability 2019, 11, 1528. [CrossRef]

14. Yue, W.; Changhong, S.; Xianghong, Z.; Wei, Y. Design of new intelligent street light control system. In Proceedings of the 8th IEEE International Conference on Control and Automation, Xiamen, China, 9-11 June 2010; pp. 1423-1427.

15. Cohen, B.; Muñoz, P. Sharing cities and sustainable consumption and production: Towards an integrated framework. J. Clean. Prod. 2016, 134, 87-97. [CrossRef]

16. Available online: http://www.prnewswire.com/news-releases/global-led--smart-street-lighting-market-2015-2025-30027748 6.html (accessed on 12 December 2020).

17. Available online: www.theclimategroup.org (accessed on 15 December 2020).

18. Available online: https://www.footprintnetwork.org/licenses/public-data-package-free/ (accessed on 20 February 2021).

19. Electricity Explained. Available online: https://www.eia.gov/energyexplained/electricity/electricity-in-the-us.php (accessed on 20 February 2021).

20. Global Emissions by Gas. Available online: https://www.epa.gov/ghgemissions/global-greenhouse-gas-emissions-data (accessed on 20 February 2021).

21. Bierman, A. Will switching to LED outdoor lighting increase sky glow? Light. Res. Technol. 2012, 44, 449-458. [CrossRef]

22. Fryc, I.; Bisegna, F.; Tabaka, P. Lighting of recreation grounds as a source of sky glow-The influence of luminaire type on this phenomenon. In Proceedings of the Environment and Electrical Engineering and 2017 IEEE Industrial and Commercial Power Systems Europe (EEEIC/I\&CPS Europe), Milan, Italy, 6-9 June 2017; pp. 1-4.

23. Cabello, A.J.; Kirschbaum, C.F. Modeling of Urban Light Pollution: Seasonal and Environmental Influence. J. Illum. Eng. Soc. 2001, 30, 142-151. [CrossRef]

24. Kowalska, J. Coloured light pollution in the urban environment. Photon Lett. Pol. 2019, 11, 93-95. [CrossRef]

25. Luginbuhl, C.B.; Boley, P.A.; Davis, D.R. The impact of light source spectral power distribution on sky glow. J. Quant. Spectrosc. Radiat. Transf. 2014, 139, 21-26. [CrossRef]

26. Czyżewski, D. Monitoring of the lighting conditions of a street illuminated with road lights equipped with LEDs. Przeglad Elektrotechniczny 2010, 86, 170-172.

27. Rabe, M.; Streimikiene, D.; Bilan, Y. The Concept of Risk and Possibilities of Application of Mathematical Methods in Supporting Decision Making for Sustainable Energy Development. Sustainability 2019, 11, 1018. [CrossRef]

28. Klaassen, N.; Scheepens, A.; Flipsen, B.; Vogtlander, J. Eco-efficient residential value creation of street lighting systems by simultaneously analyzing value, cost and eco-costs during the design and engineering phase. Energies 2020, 13, 3351. [CrossRef]

29. Bassam, N.E.; Maegaard, P.; Schlichting, M.L. Distributed Renewable Energies for Off-Grid Communities: Strategies and Technologies Toward Achieving Sustainability in Energy Generation and Supply; Elsevier: Amsterdam, The Netherlands, 2013.

30. Tvaronavičienè, M.; Prakapienè, D.; Garškaitè-Milvydienè, K.; Prakapas, R.; Nawrot, Ł. Energy Efficiency in the Long-Run in the Selected European Countries. Econ. Sociol. 2018, 11, 245-254. [CrossRef]

31. Beverland, M.; Lindgreen, A. What makes a good case study? A positivist review of qualitative case research published in Industrial Marketing Management, 1971-2006. Ind. Mark. Manag. 2010, 39, 56-63. [CrossRef]

32. Fletcher, A.J. Applying critical realism in qualitative research: Methodology meets method. Int. J. Soc. Res. Methodol. 2017, 20, 181-194. [CrossRef]

33. Lindgreen, A.; Di Benedetto, C.A.; Beverland, M.B. How to write up case-study methodology sections. Ind. Mark. Manag. 2020. [CrossRef]

34. World Population Prospects 2019; United Nations: New York, NY, USA, 2019.

35. Global Energy Demand Rose by $2.3 \%$ in 2018, Its Fastest Pace in the Last Decade. Available online: https://www.iea.org/news/ global-energy-demand-rose-by-23-in-2018-its-fastest-pace-in-the-last-decade (accessed on 16 December 2020).

36. Simionescu, M.; Bilan, Y.; Krajňáková, E.; Streimikiene, D.; Gędek, S. Renewable Energy in the Electricity Sector and GDP per Capita in the European Union. Energies 2019, 12, 2520. [CrossRef]

37. Center, B.P. Annual Energy Outlook 2020; EIA: Washington, DC, USA, 2020.

38. Xu, G.; Wang, W. China's energy consumption in construction and building sectors: An outlook to 2100. Energy 2020, 195, 117045. [CrossRef]

39. Alvarado, R.; Deng, Q.; Tillaguango, B.; Méndez, P.; Bravo, D.; Chamba, J.; Ahmad, M. Do economic development and human capital decrease nonrenewable energy consumption? Evidence for OECD countries. Energy 2020, 215, 119147. [CrossRef] 
40. Kasperowicz, R.; Štreimikienè, D. Economic growth and energy consumption: Comparative analysis of V4 and the "old" EU countries. J. Int. Stud. 2016, 9, 181-194. [CrossRef] [PubMed]

41. Kasperowicz, R. Economic growth and energy consumption in 12 European countries: A panel data approach. J. Int. Stud. 2014, 7, 112-122. [CrossRef]

42. Available online: www.bdew.de (accessed on 8 December 2020).

43. Available online: agora-energiewende.de (accessed on 10 December 2020).

44. Available online: www.worldenergy.com (accessed on 14 December 2020).

45. World Population Review. Available online: https://worldpopulationreview.com/ (accessed on 17 December 2020).

46. Fryc, I.; Czyżewski, D.; Fan, J.; Gălăţanu, C. The Drive towards Optimization of Road Lighting Energy Consumption Based on Mesopic Vision-A Suburban Street Case Study. Energies 2021, 14, 1175. [CrossRef]

47. Eurostat Database. Available online: https:/ / ec.europa.eu/eurostat (accessed on 10 January 2021).

48. GUS (Poland Statistic Data Base). Available online: www.stat.gov.pl (accessed on 20 January 2021).

49. LED-y Na Ulicach Miast i Gmin. Available online: https:/ / www.elektro.info.pl/artykul/oswietlenie/159254,led-y-na-ulicachmiast-i-gmin (accessed on 17 December 2020).

50. Graça, P.; Camarinha-Matos, L.M. Performance indicators for collaborative business ecosystems-Literature review and trends. Technol. Forecast. Soc. Chang. 2017, 116, 237-255. [CrossRef]

51. Costa, M.A.D.; Costa, G.H.; Dos Santos, A.S.; Schuch, L.; Pinheiro, J.R. A high efficiency autonomous street lighting system based on solar energy and LEDs. In Proceedings of the 2009 Brazilian Power Electronics Conference, Bonito, Brazil, 27 September-1 October 2009; pp. 265-273.

52. Castro, M.; Jara, A.J.; Skarmeta, A.F. Smart Lighting Solutions for Smart Cities. In Proceedings of the 2013 27th International Conference on Advanced Information Networking and Applications Workshops, Barcelona, Spain, 25-28 March 2013; pp. 13741379.

53. Laura, D.i.D.L.; Houser, K.W.; Mistrick, R.G. Chapter 16-Lighting controls. In The Lighting Handbook Tenth Edition Reference and Application; Illuminating Engineering Society: New York, NY, USA, 2011.

54. Scholtz, B.; Kapeso, M.; Van Belle, J.P. An Internet of Things (IoT) Model for Optimising Downtime Management: A Smart Lighting Case Study. In IFIP International Internet of Things Conference; Springer: Cham, Switzerland, 2018; pp. 89-104.

55. Strous, L.; Cerf, V.G. Internet of Things. Information Processing in an Increasingly Connected World: First IFIP International Cross-Domain Conference, IFIPIoT 2018. In Proceedings of the 24th IFIP World Computer Congress, WCC 2018, Poznan, Poland, 18-19 September 2018.

56. Rabaza, O.; Peña-García, A.; Pérez-Ocón, F.; Gómez-Lorente, D. A simple method for designing efficient public lighting, based on new parameter relationships. Expert Syst. Appl. 2013, 40, 7305-7315. [CrossRef]

57. Carli, R.; Dotoli, M.; Cianci, E. An optimization tool for energy efficiency of street lighting systems in smart cities. IFACPapersOnLine 2017, 50, 14460-14464. [CrossRef]

58. Wu, Y.; Shi, C.; Zhang, X.; Yang, W. Design of New Intelligent Street Light Control System. In IEEE ICCA 2010; Institute of Electrical and Electronics Engineers (IEEE): New York, NY, USA, 2010; pp. 1423-1427.

59. Pizzuti, S.; Annunziato, M.; Moretti, F. Smart street lighting management. Energy Effic. 2013, 6, 607-616. [CrossRef]

60. Novak, T.; Pollhammer, K.; Zeilinger, H.; Schaat, S. Intelligent streetlight management in a smart city. In Proceedings of the 2014 IEEE Emerging Technology and Factory Automation (ETFA), Barcelona, Spain, 16-19 September 2014; pp. 1-8.

61. Bachanek, K.H.; Puzio, E.; Tundys, B. Management of ICT Technologies in the Smart City Research-Bibliometric Analysis. In Proceedings of the 36th International Business Information Management Association Conference 2020, IBIMA, Granada, Spain, 4-5 November 2020; pp. 6128-6137.

62. Grubler, A. Energy transitions research: Insights and cautionary tales. Energy Policy 2012, 50, 8-16. [CrossRef]

63. Karunakaran, K.; Shanmugasundaram, N.; Pradeep-Kumar, S. Analysis of Smart Energy Supply to Smart City. Int. J. Pure Appl. Math. 2018, 118, 757-762.

64. Wojnicki, I.; Kotulski, L. Improving Control Efficiency of Dynamic Street Lighting by Utilizing the Dual Graph Grammar Concept. Energies 2018, 11, 402. [CrossRef]

65. Lim, Y.; Edelenbos, J.; Gianoli, A. Smart Energy Transition: An Evaluation of Cities in South Korea. Informatics 2019, 6, 50. [CrossRef]

66. Available online: https:/ / mnre.gov.in/ (accessed on 15 December 2020).

67. Invest to Save-Changing to LED Street Lighting on London's (TfL) Road Network. Available online: http://www.ppmctransport.org/invest-to-save-changing-to-led-street-lighting-on-londons-tfl-road-network/ (accessed on 19 December 2020).

68. Singapore Aims to Convert All Roads to Smart LED Street lighting Systems by 2022. Available online: https:/ /www.ledinside. com/news/2017/1/singapore_aims_to_convert_all_roads_to_smart_led_streetlighting_systems_by_2022 (accessed on 19 December 2020).

69. Chicago is Undertaking One of the Largest Street Lighting Modernization Programs in the Country. Available online: https: / / chicagosmartlighting-chicago.opendata.arcgis.com/ (accessed on 19 December 2020).

70. Städtebaulicher Masterplan Innenstadt Köln. Available online: http://www.masterplan-koeln.de/fileadmin/Content/PDF/ Entwicklung_Masterplan_gesamt_komprimiert.pdf (accessed on 15 December 2020).

71. Available online: www.lighting.philips.pl (accessed on 17 December 2020). 
72. Czas na "Sowę"—Rusza Program Modernizacji Oświetlenia. Available online: https://www.um.warszawa.pl/aktualnosci/czasna-sow-rusza-program-modernizacji-o-wietlenia (accessed on 15 December 2020).

73. Mapped: The 1.2 Billion People without Access to Electricity. Available online: https://www.visualcapitalist.com/mappedbillion-people-without-access-to-electricity/ (accessed on 14 December 2020).

74. Kliestik, T.; Valaskova, K.; Nica, E.; Kovacova, M.; Lazaroiu, G. Advanced methods of earnings management: Monotonic trends and change-points under spotlight in the Visegrad countries. Oeconomia Copernic. 2020, 11, 371-400. [CrossRef]

75. Stávková, J.; Maroušek, J. Novel sorbent shows promising financial results on P recovery from sludge water. Chemosphere 2021, 276, 130097. [CrossRef]

76. Kliestik, T.; Nica, E.; Musa, H.; Poliak, M.; Mihai, E.A. Networked, Smart, and Responsive Devices in Industry 4.0 Manufacturing Systems. Econ. Manag. Financ. Mark. 2020, 15, 23-29.

77. Maroušek, J.; Maroušková, A.; Kůs, T. Shower cooler reduces pollutants release in production of competitive cement substitute at low cost. Energy Sources Part A Recovery Util. Environ. Eff. 2020, 1-10. [CrossRef]

78. Valaskova, K.; Throne, O.; Kral, P.; Michalkova, L. Deep learning-enabled smart process planning in cyber-physical system-based manufacturing. J. Self-Gov. Manag. Econ. 2020, 8, 121-127.

79. Peters, E.; Kliestik, T.; Musa, H.; Durana, P. Product decision-making information systems, real-time big data analytics, and deep learning-enabled smart process planning in sustainable industry 4.0. J. Self-Gov. Manag. Econ. 2020, 8, 16-22.

80. Maroušek, J. Study on commercial scale steam explosion of winter Brassica napus straw. Int. J. Green Energy 2013, $10,944-951$. [CrossRef]

81. Jandačka, J.; Mičieta, J.; Holubčík, M.; Nosek, R. Experimental Determination of Bed Temperatures during Wood Pellet Combustion. Energy Fuels 2017, 31, 2919-2926.

82. Lenhard, R.; Malcho, M.; Jandačka, J. Modelling of Heat Transfer in the Evaporator and Condenser of the Working Fluid in the Heat Pipe. Heat Transf. Eng. 2018, 40, 215-226. [CrossRef]

83. Hadzima, B.; Janeček, M.; Estrin, Y.; Kim, H.S. Microstructure and corrosion properties of ultrafine-grained inter-stitial free steel. Mater. Sci. Eng. A 2007, 462, 243-247. [CrossRef]

84. Maroušek, J.; Myšková, K.; Žák, J. Managing environmental innovation: Case study on biorefinery concept. Rev. Técnica Fac. Ing. Univ. Zulia 2015, 38, 216-220.

85. Cheng, C.A.; Cheng, H.L.; Chang, C.H.; Chang, E.C.; Hung, W.S.; Lai, C.C.; Lan, L.F. A Single-Stage High Power Factor Power Supply for Providing an LED Street-Light Lamp Featuring Soft-Switching and Bluetooth Wireless Dimming Capability. Energies 2021, 14, 477. [CrossRef]

86. Potenciano Menci, S.; Le Baut, J.; Matanza Domingo, J.; López López, G.; Cossent Arín, R.; Pio Silva, M. A Novel Methodology for the Scalability Analysis of ICT Systems for Smart Grids Based on SGAM: The InteGrid Project Approach. Energies 2020, 13, 3818. [CrossRef]

87. Molina-Moreno, V.; Utrilla, P.N.-C.; Cortés-García, F.J.; Peña-García, A. The Use of Led Technology and Biomass to Power Public Lighting in a Local Context: The Case of Baeza (Spain). Energies 2018, 11, 1783. [CrossRef]

88. Pérez-Chacón, R.; Luna-Romera, J.M.; Troncoso, A.; Martínez-Álvarez, F.; Riquelme, J.C. Big data analytics for discovering electricity consumption patterns in smart cities. Energies 2018, 11, 683. [CrossRef]

89. Impedovo, D.; Pirlo, G. Artificial Intelligence Applications to Smart City and Smart Enterprise. Appl. Sci. 2020, 10, 2944. [CrossRef]

90. Thornbush, M.; Golubchikov, O. Smart energy cities: The evolution of the city-energy-sustainability nexus. Environ. Dev. 2021, 100626. [CrossRef]

91. Angelakoglou, K.; Nikolopoulos, N.; Giourka, P.; Svensson, I.L.; Tsarchopoulos, P.; Tryferidis, A.; Tzovaras, D. A methodological framework for the selection of key performance indicators to assess smart city solutions. Smart Cities 2019, 2, 269. [CrossRef]

92. Leccese, F.; Salvadori, G.; Rocca, M. Critical analysis of the energy performance indicators for road lighting systems in historical towns of central Italy. Energy 2017, 138, 616-628. [CrossRef]

93. Doulos, L.T.; Sioutis, I.; Kontaxis, P.; Zissis, G.; Faidas, K. A decision support system for assessment of street lighting tenders based on energy performance indicators and environmental criteria: Overview, methodology and case study. Sustain. Cities Soc. 2019, 51, 101759. [CrossRef]

94. Richter, J.L.; Van Buskirk, R.; Dalhammar, C.; Bennich, P. Optimal durability in least life cycle cost methods: The case of LED lamps. Energy Effic. 2019, 12, 107-121. [CrossRef]

95. Barkhordar, Z.A. Evaluating the economy-wide effects of energy efficient lighting in the household sector of Iran. Energy Policy 2019, 127, 125-133. [CrossRef] 